\title{
Evolution of Pharmacy Practice in Kenya
}

\author{
Maryanne Favour Ong'udi* \\ Pharmacist, College of Health Sciences, Kenya
}

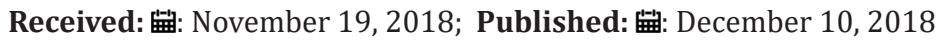

*Corresponding author: Maryanne Favour Ong'udi, Pharmacist, Nairobi, Kenya

\section{Opinion}

The imperative for pharmacists to become more patient centered is apparent and as clear as crystal, now more than ever. The work required to achieve the vision of pharmacists working in patient-oriented health care setup represents a transformational change in the evolution of the profession. Patient-centered clinical pharmacy services involves participation of the pharmacist in ward-based services that includes being part of a multi-disciplinary team that daily monitors the progress of a patient. This is from understanding the patient's history and their primary diagnosis and accounting for and rationalizing the specific indication for every drug the patient is on. This helps to avoid incidences of poly pharmacy. The accuracy of the doses is key to achieve the desired therapeutic effect. The pharmacist takes the initiative of monitoring the patient's vitals, reviewing their body systems to ensure they function well and in the event they do not, be in a position to advise the team especially on drug dosing. Patient-centered practice was associated with improved health status (less discomfort, less concern, and better mental health) and increased efficiency of care i.e fewer diagnostic tests and referrals [1]. In an observational study, some aspects of patient centeredness may have important benefits for patients: improved communication that can improve satisfaction and biomedical outcomes [2].

The patient is actually treated as person and not just a medical model and is informed and involved in the treatment process. This enhances a patient's autonomy over their health and ends up being beneficial to the patient. Sub-optimal medication use may lead to morbidity, mortality and increased costs. To reduce unnecessary patient harm, medicines management including medication reviews can be provided by clinical pharmacists [3]. Participation of a clinical pharmacist in a multi-disciplinary team is very crucial as in a systematic mini review to identify, assess and summarize the literature investigating the effect of pharmacist-led medication reviews in hospitalized patients, the studies revealed positive effects on medication use, health service use and costs [3]. The pharmacy practice in Kenya is changing as there is a shift from the former technical and dispensing roles to a focus on services that improve patient outcomes. This is a call to implore pharmacists to be agents of igniting the change they would love to see in the health care systems through positive work ethic and by realizing that the first and most noble responsibility is to the patient. Only then can we as pharmacists revolutionize health care by creating a sustainable future for all through promoting good health and wellbeing. (Sustainable Development Goal 3) [4].

\section{References}

1. Stewart M, Brown JB, Donner A, McWhinney IR, Oates J, et al. (2000) The impact of patient-centered care on outcomes. Journal of family practice 49(9): 796-804.

2. Little P, Everitt H, Williamson I, Warner G, Moore M, et al. (2001) Preferences of patients for patient centred approach to consultation in primary care: observational study. BMJ 322(7284): 468.

3. Graabæk T, Kjeldsen LJ (2013) Medication reviews by clinical pharmacists at hospitals lead to improved patient outcomes: a systematic review. Basic \& clinical pharmacology \& toxicology 112(6): 359-373.

4. Sustainable Development Goals. 
ISSN: 2574-1241

DOI: $10.26717 / B J S T R .2018 .11 .002163$

Maryanne Favour Ong'udi. Biomed J Sci \& Tech Res

(C) (P) This work is licensed under Creative

Submission Link: https://biomedres.us/submit-manuscript.php

\begin{tabular}{ll} 
BIOMEDICAL & Assets of Publishing with us \\
RESEARCHES & - Global archiving of articles \\
\hline I Immediate, unrestricted online access
\end{tabular}

